\title{
Wine Consumption Behavior and Preference of Chinese Millennials
}

\author{
--An Exploratory Investigation \\ Xiong Siran, Li Wenli* \\ Shenzhen Tourism College, Jinan University, Overseas Chinese Town, Shenzhen, 518053, Guangdong \\ Province, China \\ *corresponding author
}

Keywords: Wine market; Chinese millennial consumers; Consumer behaviour; Consumer preference

\begin{abstract}
For the wine industry, millennials are promising wine consumers in the future. This study aims to understand the wine consumption habits and style preferences of Chinese millennial consumers and how they acquire wine knowledge. An investigation was conducted in a universtiy of southern China and a total of 213 valid questionnaires were collected through electronic questionnaires. Descriptive analysis and cross-tabulation were used to understand the consumer behavior, taste and style preference of millennial consumers. The main conclusions of this study are as follows: Firstly, most millennials buy wine online. Secondly, the three most important factors of aroma and flavor characteristics that the millennials prefer are balance, aroma and softness. Thirdly, they show no difference of perference between new and old world. In addition, they like simple, easy labels and the wines with cork, etc. These conclusions are helpful for the wine industry to understand the potential wine consumer's purchase behaviour, as well as significant for the wine industry to develop the huge market of millennial consumers in the future.
\end{abstract}

\section{Introduction}

In the international wine market, millennials are a huge potential market that will influence wine consumption trends in the near future, so it is crucial to understand them. They have made wine increasingly popular all around the world and represent one of the most promising new wine consumers. According to a study conducted by OEMV, there are approximately 5.7 million wine consumers aged 18-35 in Spain, accounting for 23\% of the Spanish wine consumer population in 2008[1]. The wine market has recognized the need to focus on younger wine consumers.

Millennial consumers are generally confident, self-reliant, supportive of diversity, ambitious and fond of challenges [2]. Camillo pointed out that Chinese consumers can obtain wine information through the following channels: product reviews, word of mouth, TV ads, relevant websites, print ads and direct mail [3]. Young Chinese consumers do not know much about wine, but they have a strong desire to learn [4-7]. A survey of college students' access to wine information in Yunnan province showed that advertisements, magazines, newspapers and the Internet are the main learning channels for college students. And many expressed willingness to accept wine tastings, lectures or wineries as sources of information. They know a little about the health of wine, but not much about some of the more specialized knowledge (such as wine regions and types)[8].

In terms of purchasing channels, consumers who like to buy online are generally young people with a good level of education [9]. In terms of consumption price, Chinese consumers have different consumption prices for different consumption goals. They buy expensive wine to celebrate or give gifts, and the price of the wine they usually drink is low, which is influenced by Chinese "face culture" $[3,9,10,11]$. In terms of the type of wine, previous studies have shown that the Chinese prefer red and sweet wines to white. Chinese love and preference for food is one reason, and the influence of older generations is another. The older generation generally call wine red wine, so young people think that wine is red [3,7]. Goodman and Somogyi et al. proved that the buying factors of college students are mainly brand, texture and recommendation [11,12]. 
The wine consumption behavior has been paid more and more attention. From the perspective of behavior, economics, psychology and other aspects, such as situation, motivation, decision-making and behavior, western scholars have carried out a comprehensive study on this issue.

Previous research has shown that wine consumption is influenced by gender, age, education and income. Hussain's regression model illustrates the significant influence of age, education and income level on wine consumption behavior [13]. Compared with the socialization process of elders, young consumers regard drinking as a cultural identity and social status [14]. With the oversupply of wine market and the increasingly fierce competition, the emotional benefits consumers get from wine need to be a key mining point.

Wine consumption is affected by many factors, generally divided into two categories: the brand, varieties, prices and other characteristics of the wine itself; friends, relatives and other reference groups. Goodman reckons that for wine consumers in most countries, "taste" and "recommendations" rank among the top three buying factors [12]. Wine Intelligence conducted a survey on 1,512 Wine consumers in the UK, and found that $60 \%$ of consumers received valuable recommendations from their family and friends [15]. Consumption context is also very important, which affects the relative importance of product attributes, and consumers' purchase intention depends on the degree to which consumers relate product characteristics to consumption context [16].

Motivation drives consumption. Thach and Olsen(2006) found that one of the main reasons for drinking is that millennials like the taste of wine, followed by the pairing of wine and food, and relax. In addition, they are used to associating wine consumption with social events and prefer innovative packaging and labelling [17]. Madeira et al. have shown that in Portugal, young consumers are mainly motivated by self-experience, wine enjoyment and social interaction [18]. Wine is consumed on many occasions, as gifts, family dinners or formal dinners. Previous studies have shown that the top three motivations for wine consumption are food pairing, social interaction, and medical care[19].

Therefore, the research objective of this paper is proposed: research millennial wine consumption preferences.

\section{Methods}

The purpose of this study is to explore the wine buying behavior, wine knowledge level, taste and style preference of Chinese millennial consumers. The research was conducted in shenzhen, a dynamic and young city with a population dominated by young people, so it has a strong representation of millennial wine consumers across the country. This study uses electronic questionnaires to conduct online surveys, mainly to survey consumers aged 18-30.

\subsection{Research Questionnaire}

This questionnaire consists of three parts: wine purchasing behavior, wine taste, style preference and demographic data. The first part is about the respondents' purchase frequency, purchase volume, purchase reasons, purchase channels, price, etc. The second part is the investigation of consumers' personal preference in varieties, producing areas, wine labels, acidity and tannins. Finally, demographic information of respondents is collected. In the second part, this study referred to the professional book "GREAT WINE MADE SIMPLE" to make the investigation of taste and style more comprehensive.

\subsection{Samples and Data Collection}

This study used online survey to collect data. The survey spans 24 days from November 3, 2019 to November 26, 2019. A total of 214 questionnaires were collected, of which 213 were valid. As the interviewees are very interested in wine, they have given full understanding and active cooperation, and the questionnaire is of high quality. 


\subsection{Data Analysis}

Sort out the collected data and input it into SPSS software. In this study, descriptive analysis was used to understand the consumption habits, preferences of Chinese millennial consumers. Crosstabulation was used to analyze the relationship between wine consumption behavior, taste style preference and consumers' personal background information. A Likert scale from 1 (strongly disagree) to 5 (strongly agree) is applied to some of the survey items expressing degree.

\section{Results of Discussion}

\subsection{Wine consumption behavior}

As shown in Table 1, in terms of purchase frequency, most people did not purchase alcohol in the most recent year (29.1\%), 27.2\% bought it every six months, and 19.7\% bought it every year. As shown in Table 2, in terms of the price of wine, most people (78.9\%) would choose a wine of 100300 yuan, followed by $300-500$ yuan $(32.4 \%)$ and $\leqslant 100$ yuan $(27.2 \%)$. The data suggest that millennial consumers have limited purchasing power.

As shown in Table 3,84.1\% of people consider their knowledge of wine to be average or above.

As shown in Table 4, most people will choose the Internet (68.5\%) as the purchase channel, which reflects the great impact of the Internet on millennials. In addition, $43.2 \%$ of consumers still choose supermarkets as the purchase channel, indicating that many millennials may have low professional level on the one hand, and may also be limited by limited income on the other hand.

As shown in Table 5, 74.2\% of people drink alcohol for friends' parties, followed by $61 \%$ who choose daily drinking, and some people drink alcohol to celebrate (51.6\%) and give gifts (30\%). The proportion of business banquets, investments and collections is less than 10 percent. It shows that social interaction and self-enjoyment are the biggest goals for millennial consumers.

Table 1 Frequency of wine purchase (Multiple choices)

\begin{tabular}{|c|c|c|}
\hline Frequency & $\mathrm{N}$ & Percent of Cases \\
\hline At least once a week & 10 & $4.7 \%$ \\
\hline Once every two weeks & 13 & $6.1 \%$ \\
\hline Once a month & 28 & $13.1 \%$ \\
\hline Semiannually & 58 & $27.2 \%$ \\
\hline Once a year & 42 & $19.7 \%$ \\
\hline Not once & 62 & $29.1 \%$ \\
\hline Total & 213 & $100 \%$ \\
\hline
\end{tabular}

Table 2 Price (Multiple choices)

\begin{tabular}{|c|c|c|}
\hline Price[yuan] & $\mathrm{N}$ & Percent of Cases \\
\hline$\leq 100$ & 58 & $27.2 \%$ \\
\hline $100-300$ & 168 & $78.9 \%$ \\
\hline $300-500$ & 69 & $32.4 \%$ \\
\hline $500-1000$ & 19 & $8.9 \%$ \\
\hline $1000-3000$ & 8 & $3.8 \%$ \\
\hline$>3000$ & 1 & 0.5 \\
\hline Total & 323 & $151.7 \%$ \\
\hline
\end{tabular}

Table 3 Knowledge of wine

\begin{tabular}{|c|c|c|}
\hline Score & $\mathrm{N}$ & Percent of Cases \\
\hline 1 & 4 & $1.9 \%$ \\
\hline 2 & 30 & $14.1 \%$ \\
\hline 3 & 119 & $55.9 \%$ \\
\hline 4 & 52 & $24.4 \%$ \\
\hline 5 & 8 & $3.8 \%$ \\
\hline Total & 213 & $100 \%$ \\
\hline
\end{tabular}


Table 4 Purchase channels (Multiple choices)

\begin{tabular}{|c|c|c|c|c|c|}
\hline Channel & $\mathrm{N}$ & Percent of Cases & Channel & $\mathrm{N}$ & Percent of Cases \\
\hline Supermarket & 92 & $43.2 \%$ & Bar & 7 & $3.3 \%$ \\
\hline Liquor store & 67 & $31.5 \%$ & Hotel & 5 & $2.3 \%$ \\
\hline Online purchase & 146 & $68.5 \%$ & Other & 32 & $15.0 \%$ \\
\hline & & & Total & 349 & $163.8 \%$ \\
\hline
\end{tabular}

Table 5 The reason for buying wine (Multiple choices)

\begin{tabular}{|c|c|c|c|c|c|}
\hline Reason & $\mathrm{N}$ & Percent of Cases & Reason & $\mathrm{N}$ & Percent of Cases \\
\hline Daily drinking & 130 & $61.0 \%$ & Gift giving & 64 & $30.0 \%$ \\
\hline Friends party & 158 & $74.2 \%$ & Investment & 5 & $2.3 \%$ \\
\hline The celebration & 110 & $51.6 \%$ & Collection & 10 & $4.7 \%$ \\
\hline Business banquets & 19 & $8.9 \%$ & Other & 13 & $6.1 \%$ \\
\hline & & & Total & 509 & $238.8 \%$ \\
\hline
\end{tabular}

\subsection{Wine consumption behavior}

As shown in Table 6, the grape variety (Mean=3.96), price (Mean=3.96) and the original production (Mean=3.95) are the three most important factors for millennial consumers to judge the quality of a wine.

As shown in Table 7, the three most important factors for aroma and flavor characteristics are balance (sweetness, acidity and combination of tannins) (Mean=4.43), aroma (Mean=4.30) and softness (Mean=4.28). As shown in Table 8, for the description of taste preference, the statements with a high average score are "I like subtle and elegant wines" (Mean=4.04), "I like sweet wines" (Mean=3.74), "I like wines that are fruity and bold" (Mean=3.82), and "I like wine with the aroma of age" (Mean=3.68). "Heavy body, low alcohol content, high acidity and heavy tannins" all had an average score of less than 3.5, showing no obvious tendency. As can be seen from the data in Table 10 and Table 11, the wines of France (81.2\%), Italy (48.4\%) and Germany (33.8\%) are the most preferred wines, and Riesling (77.9 percent), sauvignon sauvignon (44.1 percent) and cabernet sauvignon (43.2 percent) were also preferred.

As shown in Table 9, except for the description of taste preference, the statements with high average scores are "I like wines with simple and easy labels" (Mean=3.66) and "I like wines with cork” (Mean=3.64).

Table 6 External factors in judging wine quality

\begin{tabular}{|c|c|c|c|}
\hline Factors & Mean & Factors & Mean \\
\hline Prize & 3.13 & Grape varieties & 3.96 \\
\hline Brand & 3.64 & $\begin{array}{c}\text { Labels, bottles and corks -- } \\
\text { sight and feel }\end{array}$ & 3.45 \\
\hline Reputation & 3.83 & Price & 3.96 \\
\hline Country of origin & 3.81 & Wine score & 3.77 \\
\hline The original production & 3.95 & The age of the wine & 3.55 \\
\hline $\begin{array}{c}\text { Recommendations from } \\
\text { friends and family }\end{array}$ & 3.60 & The year of wine & 3.66 \\
\hline
\end{tabular}

Table 7 Aroma and flavor characteristics that determine wine quality

\begin{tabular}{|c|c|c|c|}
\hline Factors & Mean & Factors & Mean \\
\hline Color & 3.73 & Balance (combination of sweetness, acidity and tannins) & 4.43 \\
\hline Aroma & 4.30 & Aftertaste & 4.16 \\
\hline Acidity & 4.08 & Palate (body) & 4.25 \\
\hline Sweetness & 4.10 & Softness & 4.28 \\
\hline Alcohol content & 3.63 & Complexity/hierarchy & 4.18 \\
\hline Tannins & 3.97 & Change in taste & 4.03 \\
\hline Oak & 3.47 & & \\
\hline
\end{tabular}


Table 8 Taste preferences

\begin{tabular}{|c|c|}
\hline Description & Mean \\
\hline I like heavy - bodied wines. & 3.12 \\
\hline I like low alcohol wines. & 3.40 \\
\hline I like wines with high acidity. & 3.24 \\
\hline I like the structure of wines with heavy tannins. & 3.13 \\
\hline I like sweet wines. & 3.74 \\
\hline I like wines that are fruity and bold. & 3.82 \\
\hline I like subtle and elegant wines. & 4.04 \\
\hline I like wine with the aroma of age. & 3.68 \\
\hline
\end{tabular}

Table 9 Style preference (except taste)

\begin{tabular}{|c|c|}
\hline Description & Mean \\
\hline I like wines with simple labels. & 3.12 \\
\hline $\begin{array}{c}\text { Wine labels with a sense of The Times, innovation and artistry are more } \\
\text { attractive for me to buy. }\end{array}$ & 3.40 \\
\hline I like wine with cork. & 3.24 \\
\hline I like wine with screw caps. & 3.13 \\
\hline Grape marketing influences my purchasing decisions. & 3.74 \\
\hline
\end{tabular}

Table 10 Favorite country of origin (Multiple choices)

\begin{tabular}{|c|c|c|c|c|c|}
\hline Country & $\mathrm{N}$ & Percent of Cases & Country & $\mathrm{N}$ & Percent of Cases \\
\hline France & 173 & $81.2 \%$ & New Zealand & 49 & $23.0 \%$ \\
\hline Italy & 103 & $48.4 \%$ & Chile & 53 & $24.9 \%$ \\
\hline Spain & 56 & $26.3 \%$ & Argentina & 18 & $8.5 \%$ \\
\hline German & 72 & $33.8 \%$ & South Africa & 11 & $5.2 \%$ \\
\hline America & 35 & $16.4 \%$ & China & 31 & $14.6 \%$ \\
\hline Australia & 67 & $31.5 \%$ & Other & 2 & $0.9 \%$ \\
\hline & & & Total & 670 & $314.7 \%$ \\
\hline
\end{tabular}

Table 11 Favorite grape variety (Multiple choices)

\begin{tabular}{|c|c|c|c|c|c|}
\hline Variety & $\mathrm{N}$ & Percent of Cases & Variety & $\mathrm{N}$ & Percent of Cases \\
\hline Cabernet sauvignon & 92 & $43.2 \%$ & Chardonnay & 71 & $33.3 \%$ \\
\hline Merlot & 52 & $24.4 \%$ & Sauvignon blanc & 94 & $44.1 \%$ \\
\hline Syrah & 62 & $29.1 \%$ & Riesling & 166 & $77.9 \%$ \\
\hline Grenache & 38 & $17.8 \%$ & Other & 13 & $6.1 \%$ \\
\hline Pinot noir & 79 & $37.1 \%$ & Total & 667 & $313 \%$ \\
\hline
\end{tabular}

\section{Conclusion and Recommendation}

The Internet is increasingly influencing Chinese millennials' wine consumption. Most people buy wine online. So the wine industry can focus on the public accounts related to wine, keep updated frequency, improve the quality of the content, and also can try to present it in the form of advertorials and short videos that young people prefer. Wineries try to open online stores on reliable platforms as far as possible, which can effectively increase sales.

Wine education is very important. At present, some universities have offered wine related courses. The wine industry could consider partnering with universities and training institutions to offer more wine courses. The basic courses can be used to open the door of the wine world to millennials who have never been exposed to wine. Advanced courses can give consumers a deeper level of knowledge, leading to a stronger interest in wine.

Wine marketing needs to be tailored to the characteristics of millennial consumers. The main reasons young consumers buy wine are to celebrate, give gifts and enjoy the wonderful taste of wine. Therefore, wine marketing can pay attention to highlight these characteristics, can add gift boxes, festive gift boxes, etc. And advertising can highlight the self-enjoyment of the picture. For the most important aroma and flavor characteristics that consumers feel, wine marketing should 
highlight the description of a wine balance, aroma and softness. In order to adapt to the fast pace of The Times, they should design simple and easy to understand wine label as far as possible. And millennials prefer wine with cork.

Young consumers like both elegant and delicate wines and wines that are fruity and unrestrained, so there is no obvious tendency toward the old and new world in taste. Therefore, young consumers are important market segments for both new world and old world wines.

This study has certain reference significance for the wine market, which is conducive to developing the huge potential market of millennials. Anyway, there are still some shortcomings for this study. The survey should be conducted in more areas of the country to collect data on consumers in more cities, so as to make the sample size more representative. In addition, the current efforts of the wine market aimed at millennials are not covered much in this study. In addition to the research on consumers, the research on market suppliers is also indispensable.

\section{References}

[1] Magistris, T.D., Groot, Etiénne, Gracia, A. and Albisu, L.M. (2011) Do Millennial generation’s wine preferences of the "New World" differ from the "Old World"? A pilot study. International Journal of Wine Business Research, 2, 145-160.

[2] Tulgan, B., Martin, C.A.: Managing Generation Y: global citizens born in the late seventies and early eighties (HDR Press, New York, 2001).

[3] Camillo, A.A. (2012) A strategic investigation of the determinants of wine consumption in China. International Journal of Wine Business Research, 1, 68-92.

[4] Wang, A.Y.: The cognition and consumption of teachers and college students-an investigation in Qinhuangdao (Ph.D., Northwest A\&F University, China 2007). [In Chinese]

[5] Chai, J.H., Zhang, L.M., Cui, Y.Z., Rong, B.H. and Shi, P.B. (2007) The college students' acknowledge and behavior-an investigation in Qinhuangdao. Sino-Overseas Grapevine \& Wine, 5, 57-61. [In Chinese]

[6] Li, J.G., Dai, L. (2007) The cognition and consumption preference of college students- a case study in Northwest A\&F University. Liquor-Making Science \& Technology, 1, 105-107. [In Chinese]

[7] Li, J.G., Jia, J.R., Taylor, D., Bruwer, J. and Li, E. (2011) The wine drinking behaviour of young adults: an exploratory study in China. British Food Journal, 10, 1305-1317.

[8] Ma, C.H., Shao, J.H. and Ma, J. (2010) The cognition and consumption of students towards wine- a case study in Kunming. Liquor-Making Science \& Technology, 9, 95-98. [In Chinese]

[9] Yi, D.: The study of wine consumers' behavior in Shanghai (Ph.D., Fudan University, China 2007). [In Chinese]

[10] Yu, Y., Ma, H.Q. and Luo, G.G. (2005) A preliminary investigation on the cognition and purchasing of Beijing's young consumers toward Wine. Sino-Overseas Grapevine \& Wine, 6, 55-57. [In Chinese]

[11] Somogyi, S., Li, E., Johnson, T., Johan, B. and Susan, B. (2011) The underlying motivations of Chinese wine consumer behaviour. Asia Pacific Journal of Marketing and Logistics, 4, 473-485.

[12] Goodman, S. (2009) An international comparison of retail consumer wine choice. International journal of wine business research, 1, 41-49.

[13] Hussain, M., Cholette and Castaldi, S. R. (2007) Determinants of wine consumption of US consumers: an econometric analysis. International Journal of Wine Business Research, 1, 49-62.

[14] Bruwer, J. (2005) Consumer household role structures and other influencing factors on winebuying and consumption. Australian \& New Zealand Grapegrower \& Winemaker, Vol.503, 50-58. 
[15] Wine Intelligence. (2008) Decisions, decisions: How UK consumers choose their wines. The wine intelligence briefing, Vol.11, 1-4.

[16] Quester, P.G., Smart, J. (1998) The influence of consumption situation and product involvement over consumers' use of product attribute. Journal of consumer marketing, 3, 220-238.

[17] Thach, E.C., Olsen, J.E. (2006) Market segment analysis to target young adult wine drinkers. Agribusiness, 3, 307-22.

[18] Madeira, J., Duarte, F. and Barreira, M.M. (2009) Wine purchase and consumption behaviour of young adults in Portugal: Is age a differentiation factor. OEnometrie, 5, 1-10.

[19] Xiong, R., Li, W.L. (2017) The wine consumption and purchase behavior of college students: an investigation in the South of China. Universal Journal of Management, 6, 271-277. 